\title{
Acute Lymphoblastic Leukemia by ROSE Cluster
}

National Cancer Institute

\section{Source}

National Cancer Institute. Acute Lymphoblastic Leukemia by ROSE Cluster. NCI

Thesaurus. Code C121978.

Unique gene expression-based patient cluster groups in high-risk B-precursor acute lymphoblastic leukemia determined by Recognition of Outliers by Sampling Ends (ROSE). 